\title{
Research on Graduation Design Teaching of Product Design Major based on Innovative Entrepreneurship Education
}

\author{
ZHANG Hai-chao1, WANG Li1*,WANG Qiang2, \\ 1 Dalian Institute of Science and Technology China \\ 2 Dalian Jiaotong University, China
}

\begin{abstract}
Graduation design is an important practical link in the cultivation of product design professionals. Under the background of innovative entrepreneurship education, new requirements are put forward for graduation design teaching. Graduation design is not only the demonstration of teaching achievements, but also the focus of teaching reform. This paper enhances the product design education innovation and entrepreneurship awareness mainly through the analysis of the current graduation design teaching problems, the innovative concept of entrepreneurship, and the reform of organizational forms, quality standards and evaluation of graduation design.
\end{abstract}

Keywords-Graduation design; Innovation and entrepreneurship; Product design

\section{INTRODUCTION}

Graduation design requires students to make comprehensive use of what they have learned in the past few years to carry out project design or design projects (simulation or reality), which is a comprehensive and systematic study of students' professional knowledge. It is also a test for students to do design work after graduation.

First of all, in the face of graduates' internship and employment demand, there is some resistance to the development of graduation design teaching. Many students will choose to work outside school during the graduation design teaching week and lack of communication with the teachers, so the whole teaching management process is loose, which seriously affects the smooth development of graduation design teaching and the quality of final works.

Secondly, in recent years, the quality of design education has been affected under the background of large enrollment expansion of design majors. The expansion of student enrollment will inevitably lead to the decline in quality. There will be many students who are not in the right attitude towards major study, and even some graduates have the idea that graduation design can pass the exam. In addition, the teacher will consider the topic from a realistic point of view, not from the interests and characteristics of the students. This directly affects students' enthusiasm and does not keep their ideas innovative.

Thirdly, the organizational form of graduation design has been lack of change, especially on the topic. Basically, teachers are instructed to take the initiative according to their own research direction, while students passively choose. Although this model is more orderly to the whole management it can not stimulate and train the students' ability to think independently, and it is completely incompatible with the educational idea of cultivating students' innovative consciousness and entrepreneurial ability. However, limited by the knowledge system of guiding teachers, it can not meet the needs of practice, so that the quality of graduation design teaching can not be more effectively guaranteed.

\section{THE REFORM OF THE TEACHING MODE OF GRADUATION DESIGN UNDER THE IDEA OF INNOVATION AND ENTREPRENEURSHIP}

Colleges and universities have carried out the work of innovative entrepreneurship education in an all-round way and vigorously supported college students to carry out innovative entrepreneurial activities. This is not only the social background of the strategic measures of building an innovative country, but also the demand of the teaching reform of higher education. Cultivate students' innovative consciousness and practical ability. In order to promote the employment of college graduates, encourage and support students to start their own businesses, but also through entrepreneurship to promote employment. For product design students with good design thinking, independent entrepreneurship is a good choice. Therefore, the emphasis on cultivating students' awareness of innovation and entrepreneurship in practical teaching is in line with the needs of the times.

Graduation design education is not only the most important practical teaching, but also the inspection and display of the most important learning results of the students' professional knowledge. Therefore, it is of certain practical significance to promote the reform of graduation design and to integrate innovative and entrepreneurial education. The current graduation design teaching pays more attention to the one-sided academic nature, deviates from the market application and the feasibility, and has the big disparity with the design profession actual situation, cannot play the positive role to the student's practice ability and the design experience. This kind of graduation design teaching can not meet the needs of the market and industry, and can not play a positive 
role in the employment situation of students. In addition, it is impossible to integrate the innovative entrepreneurial practice education advocated by the state.

Therefore, it is of great practical significance to carry out the reform of graduation design under the concept of innovation and entrepreneurship, to establish a teaching mode of graduation design that can improve the quality of graduation design and expand the employment channels of graduates.

\section{REFORM OF THE ORGANIZATIONAL FORM OF GRADUATION DESIGN}

In order to guarantee the teaching quality of graduation design and integrate the idea of innovation and entrepreneurship, we need to establish a scientific and standardized organizational system.

\section{A. Implement the tutorial group system}

According to the teaching staff of the teaching and research office, the situation of the guidance teachers are analyzed one by one and arranged in groups. Each group should be dominated by a teacher with a professional title or above, with young teachers and professional designers with stronger practical abilities or part-time teachers outside school. In addition, teachers with different subjects background and specialties should be incorporated into the steering group as much as possible to make the quality of graduation design more in line with the actual needs.

\section{B. Enter the preparatory stage of graduation design ahead of time}

Identify the two-way job choices for graduate and mentor groups as early as possible before starting the graduation project. Let teachers and students communicate earlier and faster, and enter the work of graduation design in advance.

\section{Select a graduation design subject combined with a design project}

According to the idea of innovation and entrepreneurship, under the premise of teaching purpose of graduation design, the project of graduation design should be cooperated with enterprises and society as much as possible, and the practicability and application of topic selection of graduation design should be strengthened. Establish a stable outsideschool practice training base, ahead of time to organize students to the company and enterprise inspection. To discuss the interface between the graduation design choice and the enterprise project demand, and hire the enterprise designer to guide the selection. In addition, more cutting-edge or more innovative design projects should also be supported.

\section{Strengthen the testing and verification of graduation design works}

Limited by various factors, product design works generally stay in the part of design drawings, even if they have made physical models, most of them stay at the level of appearance models. If the project is no longer the actual design of the enterprise, the whole graduation project basically stays at the conceptual level. If the combination of design and production can not be more in-depth, the basic is the lack of hands-on ability and practical ability training, which is completely unable to meet the idea of innovative entrepreneurship education.

\section{E. Carrying out the process management of graduation Design}

In order to ensure the quality of graduation project and the rationality of graduation design teaching, the inspection work in three stages of prophase, metaphase and final reply is carried out. The teachers of their respective guidance groups can comprehensively track the pre-design research, design orientation, design development and design test verification, exhibition and reply of the whole process of graduation design, so as to achieve the most comprehensive management and evaluation of the graduation design of students.

\section{F. Ensure the fairness and order of the organization of graduation project reply}

The thesis reply committee and the reply team are composed of school teachers, enterprise designers and industry experts to ensure the order of the graduation design reply process. Set up a standard for evaluation and analysis of graduation design. At the same time, it is necessary to ensure that the respondent teachers can fully and deeply understand the graduation works of each student, and ensure the fairness and rationality of the graduation project reply to the greatest extent.

\section{G. Combine reply, exhibition and recruitment}

In order to maximize the effectiveness of graduation design teaching, the previous series of graduation design topics, design and production, graduation reply, graduation exhibition, enterprise docking and talent recruitment are integrated into graduation design teaching as much as possible. This is in line with the concept of innovative entrepreneurship education.

Build a good bridge between graduates and social enterprises, and promote the employment of graduates. The combination of graduation design exhibition and recruitment of talents in enterprises can make enterprises and graduates communicate directly and promote mutual understanding and employment accuracy. Graduation design works or entrepreneurial projects can be connected with enterprises with investment intention on site to realize the purpose of promoting employment and entrepreneurship through exhibition 


\section{REFORM OF GRADUATION DESIGN QUALITY STANDARD AND EVALUATION INDEXES}

The evaluation standard of graduation design quality accords with the requirements of subject and specialty education and the standard of design profession, and then carries on scientific, reasonable and objective evaluation. It focuses on the following aspects: First of all, the topic selection of graduation design is a practical project subject of enterprises or society, which not only needs to be true to the topic, but also ensures the originality of the work. Secondly, the graduation design works can reflect the students' comprehensive application of the knowledge and skills they have learned in university, at the same time, they can show their ability to analyze and solve problems autonomously, and even can have innovative ideas. Thirdly, the graduation design report should be complete, logical, clear in content, accurate in data, reasonable in design and production, and standard in text format.

According to the above quality evaluation standard, set a set of clear evaluation indicators, so as to quantify the evaluation of graduation projects. Specific evaluation indicators include topic selection, research and demonstration, design scheme and innovation, design drawings and model making, design report writing, reply performance and so on.

\section{CONCLUSION}

Design industry transformation and development, graduation design teaching is facing a complex and changeable situation. Strengthening the management of graduation design teaching and constantly reforming and innovating the teaching mode of graduation design should not only meet the background of innovation and entrepreneurship education, but also meet the needs of the development of the industry. Our country is in the development stage of Chinese design, the design subject of higher education is shouldering the important task, trying to train qualified design talents for enterprises and society.

\section{REFERENCES}

[1] Gong Lingxiao, Liu Yingli, Zhang Huijuan, and so on.The Design of Independent platform for undergraduate graduation Design Specialty [J]. Education and Teaching Forum, 2017(5): 32-33.

[2] Zhang Huijuan. Reform and practice of Multi-dimensional Cooperative graduation Design Teaching Model [J]. Vocational and Technical Education in China, 2017(2):80-83.

[3] Peng Liang. Integration and Innovation of graduation Design of Shunde Vocational and Technical College "four in one"-- 2015 graduation Design Exhibition of Furniture Design Major in Colleges and Universities [J]. Design Education, 2015 (8): 100-105.

[4] Tan Yuanyuan. Exploration of Multi-party interaction Mode for graduation Design of Industrial Design Specialty under Entrepreneurship [J]. Wireless Interconnection Technology, 2017(8):75-76. 